University of South Carolina

Scholar Commons

10-1996

\title{
Modeling interactions of browsing predation, infaunal activity and recruitment in marine soft-sediment habitats
}

Sara M. Lindsay

David S. Wethey

University of South Carolina - Columbia, wethey-david@sc.edu

Sarah A. Woodin

University of South Carolina - Columbia, woodin@sc.edu

Follow this and additional works at: https://scholarcommons.sc.edu/biol_facpub

Part of the Biology Commons

Publication Info

The American Naturalist, ed. C. Drew Harvell, Volume 148, Issue 4, 1996, pages 684-699.

(c) 1996 by the University of Chicago Press

http://www.press.uchicago.edu/index.html

This Article is brought to you by the Biological Sciences, Department of at Scholar Commons. It has been accepted for inclusion in Faculty Publications by an authorized administrator of Scholar Commons. For more information, please contact digres@mailbox.sc.edu. 


\title{
MODELING INTERACTIONS OF BROWSING PREDATION, INFAUNAL ACTIVITY, AND RECRUITMENT IN MARINE SOFT-SEDIMENT HABITATS
}

\author{
Sara M. Lindsay, ${ }^{*}$ David S. Wethey, and Sarah A. Woodin \\ Department of Biological Sciences, University of South Carolina, Columbia, South Carolina 29208
}

Submitted March 15, 1995; Revised November 13, 1995; Accepted November 17, 1995

\begin{abstract}
In marine soft-sediment habitats, the sediment surface is altered by activities of sediment dwellers (infauna). Such biogenic disturbance can influence recruitment success if settling larvae and juveniles avoid disturbed sites or if juveniles die as a result of disturbance after settling. Because infauna commonly lose exposed body parts to browsing predators and disturb less sediment as a result, we developed a simulation model to examine the interactions between browsing predation, infaunal adult activity, and recruitment. Sediment disturbance in the model was based on data for the polychaete Abarenicola pacifica. We simulated the activity of two general types of predators: prey nippers, which damaged adults only, and sediment biters, which damaged adults and consumed settled juveniles. As both types of predation rates increased, habitat rejection by settlers decreased, but juvenile mortality increased as settlers landing near damaged adults were killed when those adults resumed activity. When prey nippers were active, the interaction between predation and infaunal activity determined recruitment success, and juvenile mortality was highest at intermediate predation rates. When sediment biters were active, they controlled recruitment success by directly consuming larvae. At low adult worm densities, habitat rejection by settlers and juvenile mortality were both low, and browsing predation did not affect recruitment success. At higher adult densities, net recruitment success increased with the rate of predation by prey nippers (the magnitude of increase depended on bite rate and the length of time juveniles were susceptible to mortality), but it was never enhanced by sediment biters.
\end{abstract}

Natural disturbances play a fundamental role in the dynamics of many ecosystems. Disturbances affect resource availability (Canham and Marks 1985; Vitousek 1985), population genetic structure (Vrijenhoek 1985), and species diversity (Denslow 1985) and contribute to patchiness by creating gaps (forests: Brokaw 1985; Runkle 1985; Veblen 1985; marine invertebrate communities: Connell and Keough 1985; Sousa 1985; grasslands: Loucks et al. 1985). In marine soft-sediment habitats, animals living on and in sediments alter surrounding habitats as they burrow, build tubes, feed, and defecate. The result is a sediment landscape in constant flux, with disturbance rates dependent on the abundance and activity of organisms in the community. Because interactions among individuals in sediments are often mediated by sediment disturbance (Wilson 1990), changes in rates of biogenic disturbance are potentially significant. In particular, sediment disturbance caused by defecation and burrowing of infaunal organisms

*To whom correspondence should be addressed; E-mail: lindsay@biol.sc.edu.

Am. Nat. 1996. Vol. 148, pp. 684-699.

(c) 1996 by The University of Chicago. $0003-0147 / 96 / 4804-0006 \$ 02.00$. All rights reserved. 
can be a source of postsettlement mortality for larvae and juveniles (Brenchley 1981; Wilson 1981). Recent laboratory experiments suggest that early juvenile polychaetes and clams can detect disturbed sediments and actively reject them (Woodin and Marinelli 1991; Woodin et al. 1995). Hence, changes in sediment disturbance rates and patterns have the potential to influence recruitment success in marine sedimentary systems.

One factor that can change infaunal activity and the degree of sediment disturbance is browsing, or sublethal, predation. Sediment dwellers (infauna) such as polychaetes, bivalves, and brittlestars often lose body parts exposed above the sediment surface to predators such as demersal fishes, shrimp, and crabs (bivalve siphons: Edwards and Steele 1968; Peterson and Quammen 1982; Vlas 1985; polychaete tentacles and tails: Vlas 1979a, 1979b; Woodin 1982; Clavier 1984; Zajac 1985; brittlestar arms: Bowmer and Keegan 1983; Stancyk et al. 1994). Just as plants that are browsed by terrestrial grazers regrow tissue, browsed infauna also regenerate over time. While infauna are regenerating, however, their activity is typically reduced, often for one to several weeks (Woodin 1984; Clements 1985; Lindsay and Woodin 1992, 1995). Thus, browsing predation can create spatial and temporal gaps in adult activity, thereby producing viable recruitment sites. These gaps are ephemeral: browsing predation reduces adult activity and disturbance, and presumably juvenile mortality, but infauna gradually regenerate and return to normal activity, disturbing more sediment as they recover.

Available data suggest that browsing predators should positively influence recruitment success in marine soft-sediment habitats by reducing rates of biogenic disturbance. However, it is not clear what rates of tissue loss are necessary to cause such an increase in recruitment. Nor do we know how different types of predators will influence recruitment success. Some predators may damage only adult infauna, while others damage infauna and kill juveniles as well. We can expect the interaction among predation, adult activity, and recruitment to be modified by numerous factors including adult infaunal density and spatial pattern. This complexity makes manipulative field experiments potentially very site specific; therefore, we developed a simulation model to evaluate the importance of the interaction between browsing predation and adult activity in determining recruitment success and to identify factors on which to concentrate experimentally.

Data on sediment disturbance by intact and browsed individuals of the infaunal polychaete Abarenicola pacifica form the basis of the simulation. The model was structured so that an infaunal adult's disturbance rate was reduced by browsing; therefore, with higher rates of browsing predation, the number of intact infauna and thus the total area disturbed were reduced. Settling larvae were of an idealized species and conformed to documented behavior of several infaunal species, rejecting disturbed locations but accepting undisturbed locations. Successful settlers (juveniles) were killed if the adult at that locale returned to activity. All of these components are consistent with the experimental evidence for sedimentary systems where biogenic disturbance is important (see previously cited references).

At least two general types of epibenthic predators may be found in soft- 
TABLE 1

Disturbance Rates of Intact and Browsed Abarenicola paCifica

\begin{tabular}{lcc}
\hline \hline $\begin{array}{l}\text { Adult } \\
\text { Days since } \\
\text { Nipped }\end{array}$ & $\begin{array}{c}\text { Mean Volume of } \\
\text { Sediment Defecated } \\
\left(\mathrm{cm}^{3} / \mathrm{h}\right)\end{array}$ & $\begin{array}{c}\text { Mean Areal } \\
\text { Disturbance Rate } \\
\left(\mathrm{cm}^{2} / \mathrm{h}\right)\end{array}$ \\
\hline $\begin{array}{l}\text { Intact: } \\
>24\end{array}$ & .5456 & \\
$\begin{array}{l}\text { Browsed: } \\
<7\end{array}$ & & 1.50 \\
$7-12$ & .1900 & .52 \\
$12-18$ & .2284 & .63 \\
$18-24$ & .2697 & .74 \\
\hline
\end{tabular}

NotE. - These data (after Woodin 1984) were used to predict hourly sediment disturbance by regenerating adults. Mean areal disturbance rates were calculated assuming a plane passed through the center of an oblate spheroid.

sediment habitats: "prey-nipping" predators such as flatfish that use visual and olfactory cues to detect exposed infauna (Groot 1971) and "sediment-biting" or digging predators such as benthic-feeding fishes that not only damage adult infauna but also ingest larvae, juveniles, and more permanent meiofauna inhabiting the top 1-2 cm of sediment (e.g., estaurine fishes such as spot) (Smith and Coull 1987). We used the model to compare the effects of visual and sediment-biting predators on recruitment success. Because the total amount of sediment disturbed by infauna is clearly dependent on their density, we also examined how the density of infauna modified the effects of the different predator types on recruitment success.

\section{METHODS}

Basis for Simulations: Sediment Disturbance by Abarenicola pacifica

Abarenicola pacifica is a common polychaete occurring in the upper intertidal of False Bay, Washington $\left(48^{\circ} 29^{\prime} \mathrm{N}, 123^{\circ} 04^{\prime} \mathrm{W}\right)$. Its densities often reach 1,000 individuals per square meter (Wilson 1981), and its defecation is known to influence juveniles and small adult infauna (Brenchley 1981; Wilson 1981; Woodin 1985). The effect of tail loss on defecation by Abarenicola has been documented (Woodin 1984) as significant, long-lasting reductions in fecal production by regenerating worms. Regenerating individuals had both a reduced probability of activity and reduced fecal weights.

Using data from other studies (Woodin 1984; Krager and Woodin 1993), we determined the average weight and volume of feces produced by browsed worms that became active at different times following tail loss. These data (table 1) were used to define activity of regenerating worms over time. In the model, intact worms produce a constant volume of feces per hour (table 1). Areas covered by fecal piles were calculated by assuming fecal piles were oblate spheroids with a height-to-diameter ratio of 0.5 (Krager and Woodin 1993). 


\section{Effect of Adult Density, Browsing Rate, and Sediment-Biting Predators on Recruitment: Simulation Model}

The model describes the landscape of disturbance caused by adult Abarenicola pacifica in a $0.01-\mathrm{m}^{2}$ area. It monitors the settlement success of larvae and survival of juveniles that settled successfully. Each adult was assigned coordinates in the $0.01-\mathrm{m}^{2}$ area, a fecal production rate, an indicator of whether it had been browsed, and the time (hours) since it was browsed. Coordinates were determined by a random number generator. The hourly fecal production by regenerating adults was calculated by linear interpolation using the data in table 1 . Because the individual response to tissue loss was quite variable (Woodin 1984), we conservatively assumed that worms returned to normal activity after regenerating for $24 \mathrm{~d}$. Fecal mounds increased in the basal area for four hourly time steps and were cleared by the tide every $6 \mathrm{~h}$. The area disturbed by each worm was plotted onto a map by marking individual pixels $\left(=1 \mathrm{~mm}^{2}\right)$. Total area disturbed on the map was obtained by counting the marked pixels at each time step. The disturbance on the map changed depending on the activity of adults, although adults did not move from their original locations.

Recruits were added to random locations every $12 \mathrm{~h}$ during a 2-wk period, which simulated peaks of larval settlement. The coordinates of new recruits were compared to the disturbance on the surface map: settlers were successful only if their coordinates were not covered with feces. Sediment disturbance by fish bites was assumed not to cause rejection behavior by settling larvae. For example, at their maximum, juvenile spot (Leiostomus xanthurus) feeding pits are 2-mm deep (Billheimer and Coull 1988) and are unlikely to cause rejection behavior by settling larvae (Woodin et al. 1995). Larvae could not settle at coordinates already occupied by an adult or another juvenile. The proportion of settlers rejecting the model habitat was defined as the number of unsuccessful settlers divided by the total number of attempted settlers. Previously successful settlers, now juveniles, were monitored at every time step; if they were buried by feces or ingested by predators, they died. Like the adults, juveniles did not move from their original coordinates. Juvenile survival was monitored for $12 \mathrm{wk}$ after settlement began.

We examined two classes of predators: "sediment biters" and "prey nippers." Sediment-biting predators fed in random locations, biting circular areas (diameter $=10 \mathrm{~mm}$ ) within which all juveniles died and any adult worms were browsed. Prey-nipping predators also fed randomly but damaged only adult worms, leaving juveniles unaffected. Predation occurred only during the 4-h period around high tide. For all simulations, we recorded the hourly number of successful settlers, number of surviving juveniles, number of intact adults, and total surface area disturbed by adult worms.

\section{Details of Simulation Model Runs}

Using an hourly time step, we ran all simulations for $120 \mathrm{~d}$. During the first 30 $\mathrm{d}$, only adults were present, and they were browsed according to one of seven biting rates: $0,1,4,8,16,32$, or 64 bites in $12 \mathrm{~h}$. These rates were chosen to create a range of numbers of regenerating adults and include the range of observed 
sediment biting rates by the fish, Leiostomus xanthurus, or spot (Billheimer and Coull 1988; S. Woodin, unpublished data). Adult densities were two, five, or 10 individuals per $0.01 \mathrm{~m}^{2}$. This initial $30-\mathrm{d}$ period of predation and regeneration produced an equilibrium rate of sediment disturbance.

A pulse of settlement began at $30 \mathrm{~d}$ and ended at $44 \mathrm{~d}$. During the 2-wk settlement period, 50 potential settlers were added to the model habitat $\left(0.01 \mathrm{~m}^{2}\right)$ every $12 \mathrm{~h}(1,400$ total potential settlers added). Similar rates have been observed for settling polychaetes and bivalves (Levin 1984a; Luckenbach 1984; Feller et al. 1992). Both predation (fish bites) and adult infaunal disturbance continued throughout the settlement period and the following $10 \mathrm{wk}$ of simulation. Ten replicate simulations were run for each combination of biting rate, adult density, and predator type (sediment biters vs. prey nippers).

\section{RESULTS}

\section{Effect of Predation on Adults}

As expected from the model structure, increasing predation decreased mean numbers of intact worms at all adult densities (fig. $1 A$ ) for both sediment biters and prey nippers. With either predator type, the highest bite rate, 64 bites in $12 \mathrm{~h}$, reduced the numbers of intact worms to zero. On the average, at all adult densities, 16 bites in $12 \mathrm{~h}$ reduced the number of intact worms to two or three (i.e., 70\%-80\% occurrence of browsed individuals). Numbers of intact worms fluctuated over time as individuals regenerated (fig. $1 \mathrm{~A}$ ) or were browsed repetitively.

Because numbers of intact worms were reduced, the mean surface area of sediment disturbed by worms decreased with increasing occurrence of fish bites (fig. $1 B$ ); patterns were nearly identical whether predators were prey nippers or sediment biters. At all adult densities, sediment disburbance at 16 bites in $12 \mathrm{~h}$ was half that with no predation; at 64 bites in $12 \mathrm{~h}$, sediment disturbance was approximately one-fourth that with no predation. Total area disturbed fluctuated over time with numbers of intact worms (fig. $1 B$ ). Disturbed area was obviously dependent on adult density as well as bite rate; the weekly mean area disturbed per hour by two worms per $0.01 \mathrm{~m}^{2}$ ranged from $2 \mathrm{~cm}^{2}$ (64 bites in $12 \mathrm{~h}$ ) to 10 $\mathrm{cm}^{2}$ (zero, one, and four bites in $12 \mathrm{~h}$ ), and weekly mean area disturbed per hour by five worms per $0.01 \mathrm{~m}^{2}$ ranged from $4.5 \mathrm{~cm}^{2}$ (64 bites in $12 \mathrm{~h}$ ) to $25 \mathrm{~cm}^{2}$ (zero and one bite in $12 \mathrm{~h}$ ).

\section{Habitat Rejection by Settlers}

The percentage of settlers rejecting the habitat depended on the area disturbed by active adults and was identical for both predation scenarios. In both cases, rejection was greatest at higher adult densities with no predation (fig. $2 A$ ), which corresponds to the highest sediment disturbance rates. Increasing numbers of fish bites caused less settler rejection because less sediment was disturbed by regenerating adults. Given 10 worms per $0.01 \mathrm{~m}^{2}$ and four bites in $12 \mathrm{~h}, 44 \%$ of juveniles rejected the model habitat compared with $54 \%$ with no predation. With 

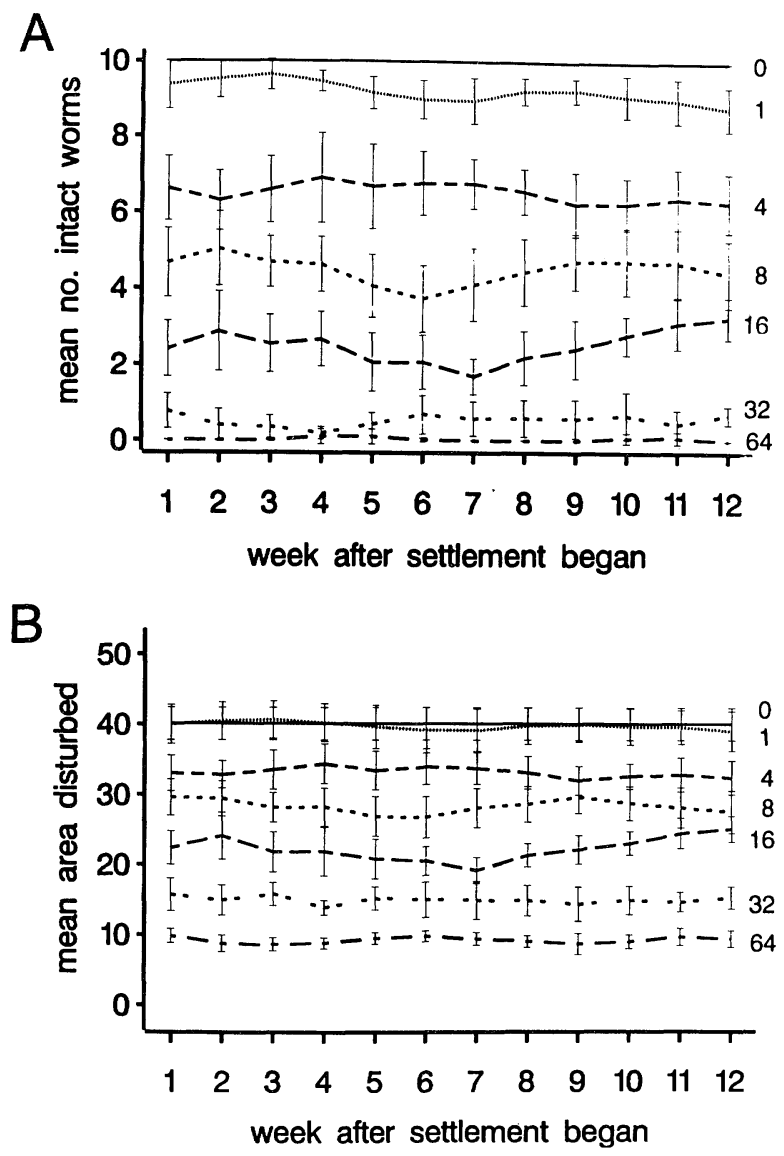

Fig. 1.-Effect of increasing predation rate on $(A)$ weekly mean numbers of intact worms (intact worms per hour) and $(B)$ weekly mean area disturbed by 10 adult worms (square centimeters per hour) during the $12 \mathrm{wk}$ after settlement began. Higher predation rates reduced numbers of intact worms and the total area disturbed. Numerals next to lines indicate the number of bites in $12 \mathrm{~h}$. Error bars indicate $2 \mathrm{SE} ; N=10$ simulations at each bite rate; there were 10 adults in each simulation. Results were nearly identical whether prey-nipping or sediment-biting predators were active; prey-nipping predator results are shown. The simulations ran for $30 \mathrm{~d}$ before the 2-wk settlement pulse began; thus, an equilibrium number of regenerating worms had been reached, and it was maintained for the remaining $12 \mathrm{wk}$.

16 and 64 bites in $12 \mathrm{~h}$, the percentages of juveniles rejecting the model habitat were $33 \%$ and $21 \%$, respectively.

Differences in the percentage of settlers rejecting the model habitat should lead to differences in absolute numbers of successful settlers. Net recruitment success will then be determined by the effects of postsettlement mortality on this initial pool of successful settlers. When bite rates were high, more settlers successfully entered the model habitat during the 2-wk settlement pulse for both predation scenarios (prey-nipping predator results shown in fig. $2 B$ ). Higher adult densities decreased the number of successful settlers (fig. $2 B$ ). 

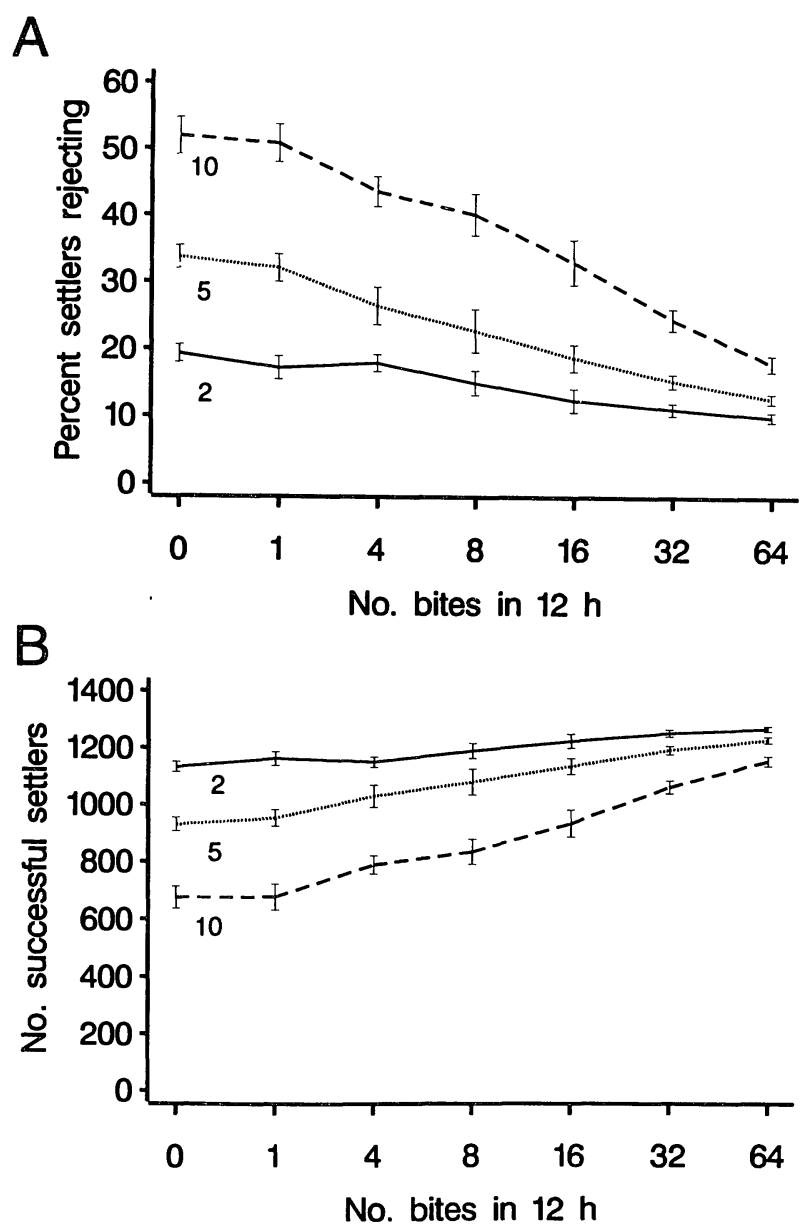

FIG. 2.-Effect of increasing predation rate and adult density on $(A)$ the mean percentage of settlers rejecting the model habitat and $(B)$ the mean number of successful settlers during the 2-wk settlement period. Numerals next to lines indicate the number of adult infauna per $0.01 \mathrm{~m}^{2}$. Error bars indicate $2 \mathrm{SE} ; N=10$ simulations at each adult density-bite rate combination. Results were identical with prey-nipping or sediment-biting predators; prey-nipping predator results are shown.

\section{Postsettlement (Juvenile) Mortality}

Postsettlement mortality is a second component determining recruitment success. Figures 3 and 4 show cumulative proportions of successful settlers (i.e., juveniles) that died following settlement in both predation scenarios. When mortality was due to both fish bites and the activity of regenerating adults (sedimentbiting predators), cumulative juvenile mortality increased with increasing bite rate, approaching $100 \%$, at all adult densities (fig. 3). In contrast, when mortality was due to the activity of regenerating adults alone (prey-nipping predators), juvenile mortality was generally lower and highly dependent on adult density (fig. 


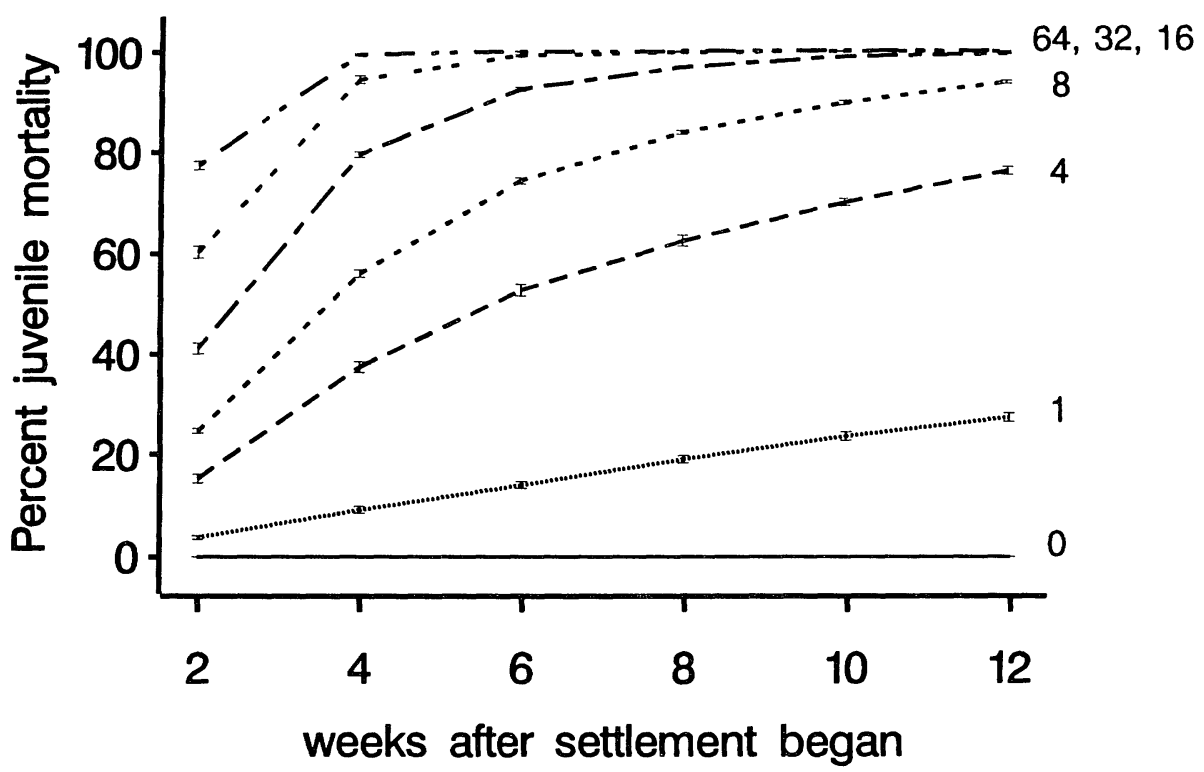

FIG. 3.-Effect of sediment-biting predators and adult infaunal activity on the cumulative percentage of juvenile mortality, for 10 adult infauna per $0.01 \mathrm{~m}^{2}$. Numerals next to lines indicate the number of bites in $12 \mathrm{~h}$. Error bars indicate $2 \mathrm{SE} ; N=10$ simulations at each bite rate. Results with five or two adults per $0.01 \mathrm{~m}^{2}$ were identical.

4). With two adults per $0.01 \mathrm{~m}^{2}$, juvenile mortality was low at all bite rates, reaching a high of $7 \%$ at $12 \mathrm{wk}$ at 16 bites in $12 \mathrm{~h}$ (fig. $4 A$ ). With 10 adults per $0.01 \mathrm{~m}^{2}$, juvenile mortality was greatest with 16 bites in $12 \mathrm{~h}$, reaching $26 \% 12 \mathrm{wk}$ after settlement began (fig. $4 B$ ). At lower bite rates, juvenile mortality stabilized at $15 \% 8 \mathrm{wk}$ after settlement began (four and eight bites in $12 \mathrm{~h}$ ) (fig. $4 B$ ).

With prey-nipping predators, cumulative juvenile mortality at $12 \mathrm{wk}$ began to drop at bite rates greater than 16 in $12 \mathrm{~h}$ (fig. 5). At the highest bite rate tested (64 bites in $12 \mathrm{~h}$ ), all adults were nipped repetitively, so very few were active at any time. Thus, juvenile mortality caused by adult activity was low. In comparison, at 16 bites in $12 \mathrm{~h}$, the frequency at which adults were nipped was lower, and most adults returned to normal activity levels for some period during the simulation. Consequently, juvenile mortality due to adult activity was greater. Juvenile mortality did not occur when all worms were intact (zero bites in $12 \mathrm{~h}$ ) because all adults were always active and settlers rejected areas disturbed by adults.

The impact of adult activity and sediment-biting predators on juvenile survival is determined in part by how long juveniles are susceptible to these sources of mortality. Because these time periods can be variable in the field and are highly taxon dependent, we used the model to examine recruitment success when juveniles were susceptible to mortality for different lengths of time. Results (fig. 6) are dramatically different for prey-nipping versus sediment-biting predators. It is clear that even when juveniles are susceptible to mortality for only short periods ( $2 \mathrm{wk})$, the additional mortality caused at high rates of sediment-biting predation 

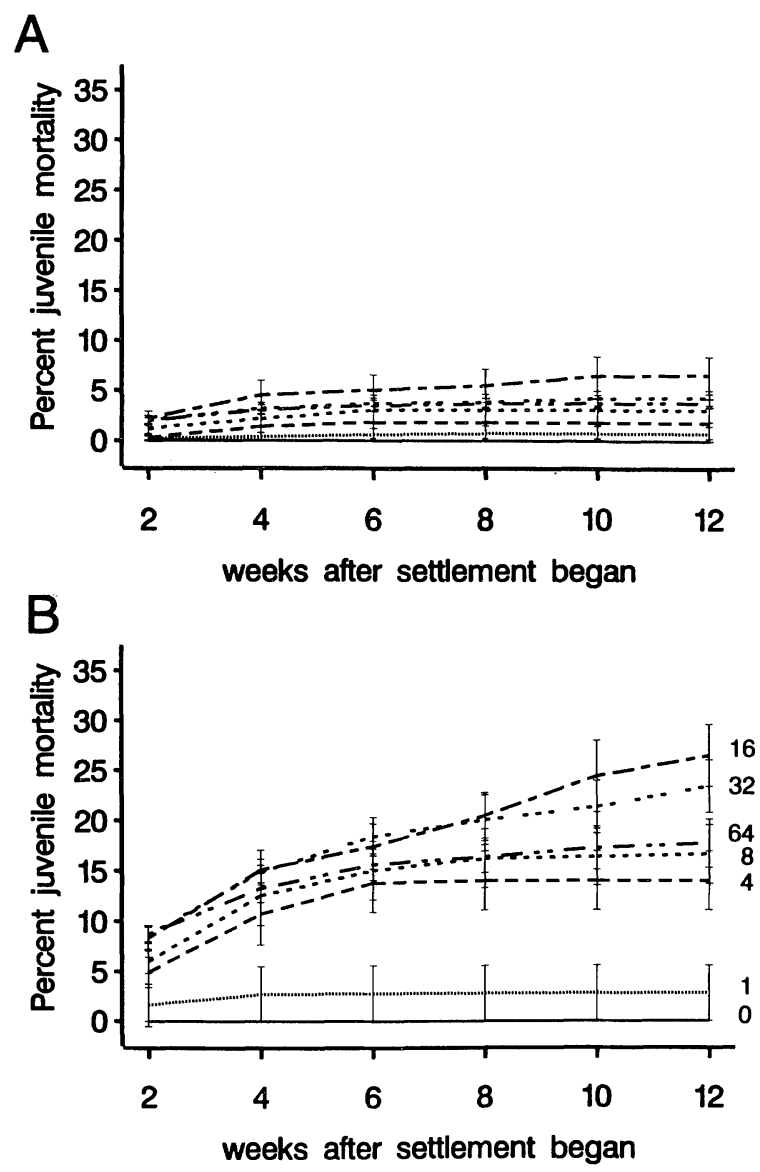

FIG. 4.-Effect of prey-nipping predators, adult infaunal activity, and adult density on the cumulative percentage of juvenile mortality. $A$, Two adult infauna per $0.01 \mathrm{~m}^{2} ; B, 10$ adults. Because prey nippers damage only adult infauna, juvenile mortality was due solely to sediment disturbance by adult infauna. Numerals next to lines indicate the number of bites in $12 \mathrm{~h}$. Error bars indicate $2 \mathrm{SE} ; N=10$ simulations at each bite rate.

completely overwhelms any enhanced settlement due to reduced activity of regenerating infauna at those predation rates. Thus, net recruitment was not significantly enhanced at any predation rate (fig. $6 B$ ). In contrast, with prey-nipping predators, increased settlement success combined with lower juvenile mortality at the highest predation rates ( 32 and 64 bites in $12 \mathrm{~h}$ ) resulted in significantly enhanced net recruitment regardless of the length of time juveniles were susceptible (fig. 6A). At low predation rates, net recruitment was enhanced only if juveniles were susceptible for short periods ( $2 \mathrm{wk}$ ) (fig. $6 A$ ).

\section{DISCUSSION}

Based on our knowledge of sedimentary systems in which biogenic disturbances are likely to affect recruitment, we explicitly built several components 


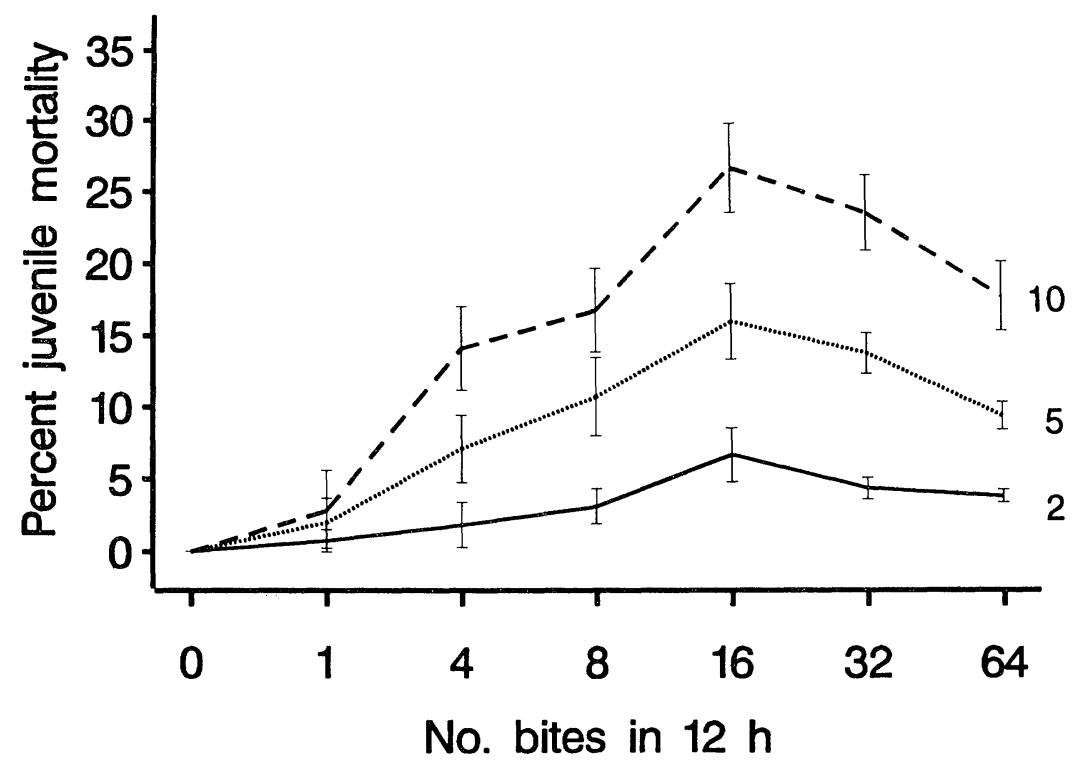

FIG. 5.-Effect of predation rate and adult density on the mean percentage of juvenile mortality $12 \mathrm{wk}$ after settlement began. Numerals next to lines indicate the number of adult infauna per $0.01 \mathrm{~m}^{2}$. Error bars indicate $2 \mathrm{SE} ; N=10$ simulations at each adult density-bite rate combination. Juvenile mortality was caused by adult sediment disturbance only (i.e., prey-nipping predators).

into the model. First, settling larvae actively reject habitats disturbed by infauna (Woodin et al. 1995). Second, juveniles within the area disturbed by an adult will die or emigrate from the system (Brenchley 1981; Wilson 1981). Within the model such juveniles die. Third, adult infaunal activity is reduced by browsing predation (Woodin 1984; Clements 1985; Lindsay and Woodin 1992, 1995). Thus, from the structure of the model we expected the number of intact worms and area disturbed to be a negative function of browsing rate (fig. 1); habitat rejection by settlers to be a negative function of browsing rate, with more dramatic effects at higher densities of adult infauna (fig. 2); and, with browsing predators, juveniles to continue dying over time (figs. 3,4) because adults that were inactive at the time of settlement because of tissue loss eventually recover and return to activity. All of these expectations from the model's structure were borne out, as shown in the designated figures.

In contrast to the results for settlement success, juvenile mortality was highly dependent on the type of predator modeled. In model runs with "prey-nipping" predators, only adult infauna were damaged. Therefore, the only source of juvenile mortality was through the activity of regenerating adults. When adult densities were low, there was no effect of browsing predation rate on juvenile mortality, which remained low, approximately 5\% (fig. 4A). At common field densities for Abarenicola pacifica (10 adults per $\left.0.01 \mathrm{~m}^{2}\right)$, juvenile mortality was greatest (ca. 26\%) at the intermediate bite rate (16 in $12 \mathrm{~h}$ ) and decreased at the highest bite rate tested (fig. 5). At the lowest bite rates, fewer adults were regenerating, 

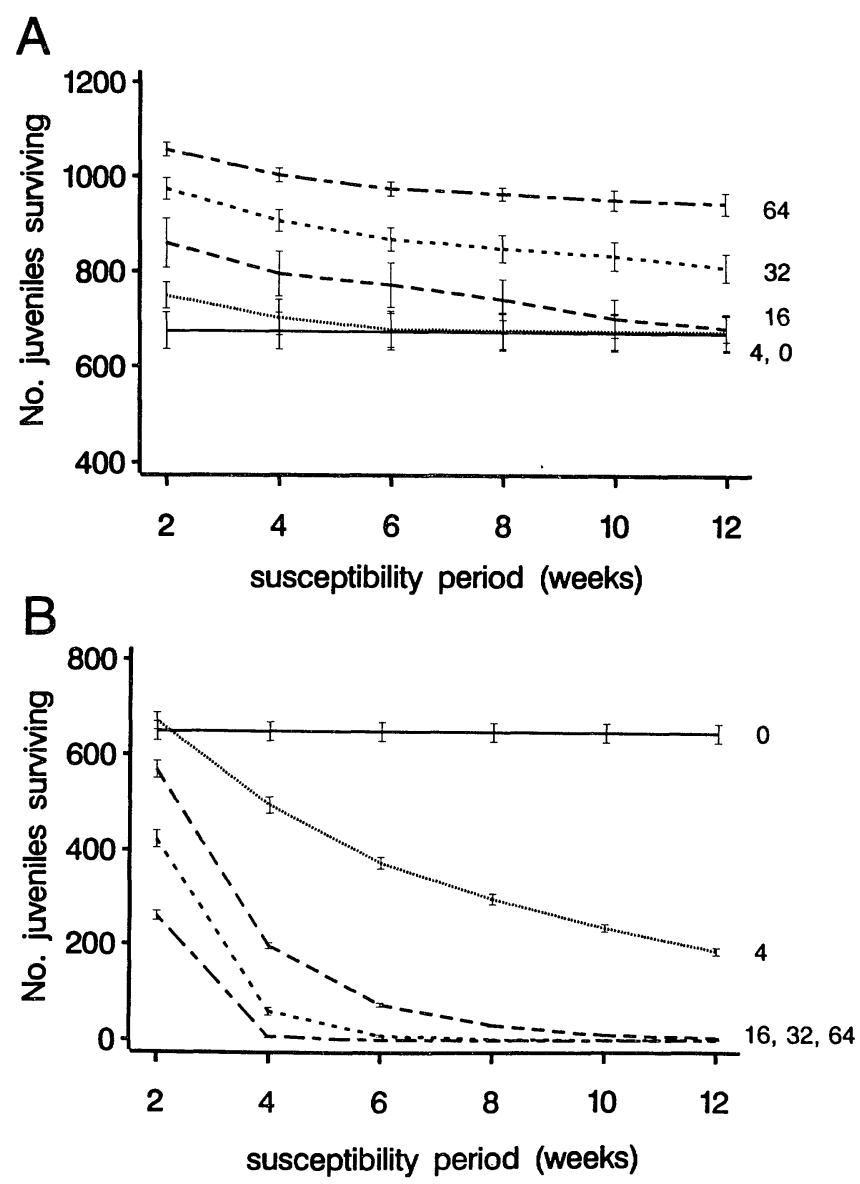

FIG. 6.-Relationship between juvenile susceptibility period and net recruitment success, where net recruitment success is determined by the balance between settlement success and postsettlement juvenile mortality. Illustrated here are mean numbers of juveniles surviving after $12 \mathrm{wk}$ given different periods of susceptibility to adult activity and predators. Juvenile mortality was caused $(A)$ only by adult activity (prey-nipping predators) or $(B)$ by adult activity and sediment-biting predators. Numerals next to lines indicate the number of bites in $12 \mathrm{~h}$. Error bars indicate $2 \mathrm{SE}, N=10$ simulations at each bite rate; there were 10 adults in each simulation, and the total possible number of survivors was 1,400 .

and more surface area was disturbed for a greater proportion of the simulation time. Because successful settlers rejected disturbed sites, relatively few landed near regenerating adults; thus, subsequent juvenile mortality was low since most settlers were outside areas that could be disturbed by intact or regenerating adults. At intermediate predation rates, more adults were regenerating and settlement success was greater because less sediment surface was disturbed initially. As adults returned to normal activity, however, successful settlers were buried and juvenile mortality therefore increased, which caused the peak in mortality 
(fig. 5). At the high bite rates, the adults rarely recovered from browsing, so settled larvae rarely died from burial by defecation. Most important, no matter how high the rate of prey-nipping activity was, juvenile mortality was much less than $100 \%$ at all adult infaunal densities (figs. 4, 5). Therefore, the enhanced settlement seen at the higher predation rates ( 32 and 64 bites in $12 \mathrm{~h}$ ) in combination with generally low juvenile mortality at these rates resulted in greater recruitment success (fig. 6). In fact, this enhancement is possible in the field, given the common occurrence of damaged infauna. Data for a closely related polychaete, Arenicola marina, which also negatively influences juvenile infauna (Flach 1992), indicate that the proportion of individuals browsed by nipping predators like flatfishes can be as high as $90 \%$ (Vlas 1979b), the same proportion of browsed individuals produced by the model at 32 bites in $12 \mathrm{~h}$.

The importance of the trade-off between enhanced settlement and higher juvenile mortality at higher bite rates is clearly dependent on time and the ability of juveniles to withstand burial by adults. We assumed that juveniles would be susceptible to burial up to $12 \mathrm{wk}$ after they settled, and, indeed, cumulative juvenile mortality increased after settlement (figs. 3,4 ). The length of time juveniles are susceptible to death via adult activity is clearly important to recruitment success (fig. 6A). Juveniles that can withstand adult disturbance early after settlement are likely to have higher recruitment success in habitats where the occurrence of regenerating adults is high. In such cases, the effect of browsing by prey-nipping predators is predominantly on settlement, not juvenile survival.

Results of the prey-nipping predator model indicate the potential influence that disturbance (or lack of it) by regenerating infauna alone may have on recruitment success. However, predators that browse adult infauna commonly ingest sediment surrounding the adult also (Groot 1971), and other predators such as bottomfeeding fishes ingest sediment, consuming meiofauna, juvenile macrofauna, and any portions of adult infauna they may have captured (Arntz 1980; Currin et al. 1984). Thus, the prey-nipping simulations represent a conservative view of the probability of juvenile mortality under different rates of browsing predation.

The sediment-biting predator model may more closely approximate the sources of juvenile mortality in the field. In contrast to results with prey-nipping predators, the impact of sediment-biting predators on juvenile survival completely overwhelmed any enhanced settlement, even if juveniles were vulnerable for only 2 wk (fig. $6 B$ ). In fact, if juveniles are susceptible to mortality for longer than 2 wk, results indicate recruitment success should be quite low even at very low predation rates. It is interesting that the positive effect of adult density on juvenile mortality seen with prey-nipping predators (fig. 5) disappeared when sedimentbiting predators were active.

Two aspects of the sediment-biting simulations affect their application to the real world. First, the predators here were modeled to bite randomly, but in the field feeding can be distinctly patchy on large and small scales (Kneib 1994). Nonrandom feeding by fishes with preference for sites with active adults could result in much higher absolute juvenile survival outside these sites because sites with adults already contain fewer settlers owing to larval rejection behavior (fig. 2), and these settlers are more likely to be killed by feeding fish. Second, just as 
the period of susceptibility to burial and predation affects juvenile mortality (fig. 6), so does the interaction between the depth of predators' bites and a juvenile's position. Older juveniles are deeper in the sediment and thus less susceptible. In this model juveniles were treated as susceptible regardless of age.

Generally, our simulation results confirm the suggestion from available data that the interaction between browsing predation and adult infaunal disturbance should influence recruitment success, but we have identified several important factors that will determine the extent to which recruitment is affected. First, the type of predator active is key; recruitment success should be higher in habitats where prey-nipping predators predominate compared with habitats where sediment-biting predators predominate. Second, if prey-nipping predators predominate, predation rates will probably have to be relatively high (i.e., causing more than $50 \%$ of infauna to be regenerating) before recruitment success is affected, and, at low adult infaunal densities, predation should have no effect on recruitment success. Third, regardless of predator type, recruitment success will be a function of the length of the juvenile susceptibility period. With prey-nipping predators, recruitment should be enhanced only when juveniles are vulnerable to mortality for short periods of time (fewer than $4 \mathrm{wk}$ ). For example, spionid polychaetes that typically mature quickly (e.g., generation times of 2-3 mo; Levin 1984b) and in some cases as soon as 2 wk after settling (Pseudopolydora kempi japonica; Strathmann 1987) are more likely to show enhanced recruitment than some bivalve juveniles that may be unable to burrow below the top $5 \mathrm{~mm}$ of sediment for at least a month (Sastry 1979). Similarly, reductions in recruitment success due to sediment-biting predators will be greatest for juveniles that are susceptible to mortality for the longest time. These predictions are all testable in the field or laboratory. Experimental priorities should include testing for the effect of predator type on recruitment success by comparing the influence of juvenile spot ("sediment biters") versus juvenile flatfish ("prey nippers") on recruitment success. Researchers should also test for the effect of juvenile susceptibility on the interaction among browsing predation, infaunal activity, and recruitment success by comparing net recruitment success under similar predation regimes when either polychaete or bivalve larvae are settling.

Our model was based on data for a single polychaete species, Abarenicola pacifica. By no means is Abarenicola unique in its effects on sediments and its spatial persistence. Other infauna are known to affect both the distributions of surrounding organisms and the properties of the sediments through their activities and to show spatial persistence, including tellinid bivalves, terebellid polychaetes, hemichordates, and thalassinid crustaceans (Aller 1982; Rhoads and Boyer 1982; Posey 1986; Woodin and Marinelli 1991). Of these, tellinid bivalves are especially subject to browsing predation (Peterson and Quammen 1982; Vlas 1985). Of necessity, we made simplifying assumptions in the model concerning movement of adults and juveniles, supply of settlers to the bottom, patterns of fish feeding, and influence of physical factors causing or removing disturbed sediment. In the field, these are all factors that will modify the basic relationship among browsing predation, infaunal activity, and recruitment success that we have identified. Given temporal and spatial persistence of disturbance by adult infauna (Krager 
and Woodin 1993), recruitment success in marine soft-sediment habitats should be a function of adult activity, and we expect browsing predation also to be an important factor influencing recruitment success.

\section{ACKNOWLEDGMENTS}

We appreciate the helpful comments made by J. Eckman, D. Harvell, P. Jumars, D. Lincoln, S. Stancyk, and an anonymous reviewer. We thank D. Pentcheff, who provided the code for the random number generator and served as a sounding board during many discussions of model structure. We especially thank E. R. W. Wethey, who would rather have gone to the beach but patiently let us wallow in cyber-poop and virtual mud instead. Financial support was provided by a National Science Foundation graduate research fellowship to S.M.L. and National Science Foundation grants IBN-9222225 to D.S.W. and R. K. ZimmerFaust and OCE-8900212 to S.A.W.

\section{LITERATURE CITED}

Aller, R. C. 1982. The effects of macrobenthos on chemical properties of marine sediment and overlying water. Pages 53-102 in P. L. McCall and M. J. Tevesz, eds. Animal-sediment relations. Plenum, New York.

Arntz, W. E. 1980. Predation by demersal fish and its impact on the dynamics of macrobenthos. Pages 121-149 in K. R. Tenore and B. C. Coull, eds. Marine benthic dynamics. University of South Carolina Press, Columbia.

Billheimer, L. E., and B. C. Coull. 1988. Bioturbation and recolonization of meiobenthos in juvenile spot (Pisces) feeding pits. Estuarine and Coastal Shelf Sciences 27:335-340.

Bowmer, T., and B. F. Keegan. 1983. Field survey of the occurrence and significance of regeneration in Amphiura filiformis (Echinodermata: Ophiuroidea) from Galway Bay, west coast of Ireland. Marine Biology 74:65-71.

Brenchley, G. A. 1981. Disturbance and community structure: an experimental study of bioturbation in marine soft-bottom environments. Journal of Marine Research 39:767-790.

Brokaw, N. V. L. 1985. Treefalls, regrowth, and community structure in tropical forests. Pages 53-70 in S. T. A. Pickett and P. S. White, eds. The ecology of natural disturbance and patch dynamics. Academic Press, Orlando, Fla.

Canham, C. D., and P. L. Marks. 1985. The response of woody plants to disturbance: patterns of establishment and growth. Pages 197-217 in S. T. A. Pickett and P. S. White, eds. The ecology of natural disturbance and patch dynamics. Academic Press, Orlando, Fla.

Clavier, J. 1984. Production due to regeneration by Euclymene oerstedi (Claparède) (Polychaeta: Maldanidae) in the marine basin of the Rance (Northern Brittany). Journal of Experimental Marine Biology and Ecology 75:97-106.

Clements, L. A. J. 1985. Post-autotomy feeding behavior of Micropholis gracillima (Stimpson): implications for regeneration. Pages 609-615 in B. F. Keegan and B. D. S. O'Connor, eds. Proceedings of the Fifth International Echinoderm Conference. Balkema, Rotterdam.

Connell, J. H., and M. J. Keough. 1985. Disturbance and patch dynamics of subtidal marine animals on hard substrate. Pages 125-151 in S. T. A. Pickett and P. S. White, eds. The ecology of natural disturbance and patch dynamics. Academic Press, Orlando, Fla.

Currin, B. M., J. P. Reed, and J. M. Miller. 1984. Growth, production, food consumption, and mortality of juvenile spot and croaker: a comparison of tidal and nontidal nursery areas. Estuaries 7:451-459.

Denslow, J. L. 1985. Disturbance-mediated coexistence of species. Pages 307-323 in S. T. A. Pickett and P. S. White, eds. The ecology of natural disturbance and patch dynamics. Academic Press, Orlando, Fla. 
Edwards, R., and J. H. Steele. 1968. The ecology of O-group plaice and common dabs at Loch Ewe. I. Population and food. Journal of Experimental Marine Biology and Ecology 2: 215-238.

Feller, R. J., S. E. Stancyk, B. C. Coull, and D. G. Edwards. 1992. Recruitment of polychaetes and bivalves: long-term assessment of predictability in a soft-bottom habitat. Marine Ecology Progress Series 87:227-238.

Flach, E. C. 1992. Disturbance of benthic infauna by sediment-reworking activities of the lugworm Arenicola marina. Netherlands Journal of Sea Research 30:81-89.

Groot, S. J., de. 1971. On the interrelationships between morphology of the alimentary tract, food and feeding behaviour in flatfishes (Pisces: Pleuronectiformes). Netherlands Journal of Sea Research 5:121-196.

Kneib, R. T. 1994. Spatial pattern, spatial scale, and feeding in fishes. Pages 171-185 in D. J. Stouder, K. L. Fresh, and R. J. Feller, eds. Theory and application in fish feeding ecology. University of South Carolina Press, Columbia.

Krager, C. D., and S. A. Woodin. 1993. Spatial persistence and sediment disturbance of an arenicolid polychaete. Limnology and Oceanography 38:509-520.

Levin, L. A. 1984a. Life history and dispersal patterns in a dense infaunal polychaete assemblage: community structure and response to disturbance. Ecology 65:1185-1200.

1984b. Multiple patterns of development in Streblospio benedicti Webster (Spionidae) from three coasts of North America. Biological Bulletin (Woods Hole) 166:494-508.

Lindsay, S. M., and S. A. Woodin. 1992. The effect of palp loss on feeding behavior of two spionid polychaetes: changes in exposure. Biological Bulletin (Woods Hole) 183:440-447.

1995. Tissue loss induces switching of feeding mode in spionid polychaetes. Marine Ecology Progress Series 125:159-169.

Loucks, O. L., M. L. Plumb-mentjes, and D. Rogers. 1985. Gap processes and large-scale disturbances in sand prairies. Pages $72-83$ in S. T. A. Pickett and P. S. White, eds. The ecology of natural disturbance and patch dynamics. Academic Press, Orlando, Fla.

Luckenbach, M. W. 1984. Settlement and early post-settlement survival in the recruitment of Mulinia lateralis (Bivalvia). Marine Ecology Progress Series 17:245-250.

Peterson, C. H., and M. L. Quammem. 1982. Siphon nipping: its importance to small fishes and its impact on growth on the bivalve Protothaca staminea (Conrad). Journal of Experimental Marine Biology and Ecology 63:249-268.

Posey, M. H. 1986. Changes in a benthic community associated with dense beds of a burrowing deposit feeder, Callianassa californensis. Marine Ecology Progress Series 31:15-22.

Rhoads, D. C., and L. F. Boyer. 1982. The effects of marine benthos on physical properties of sediments: a successional perspective. Pages 3-52 in P. L. McCall and M. J. Tevesz, eds. Animal-sediment relations. Plenum, New York.

Runkle, J. R. 1985. Disturbance regimes in temperate forests. Pages 17-33 in S. T. A. Pickett and P. S. White, eds. The ecology of natural disturbance and patch dynamics. Academic Press, Orlando, Fla.

Sastry, A. N. 1979. Pelecypoda (excluding Ostreidae). Pages 113-292 in A. C. Giese and J. S. Pearse, eds. Reproduction of marine invertebrates. Vol. 5. Molluscs: pelecypods and lesser classes. Academic Press, New York.

Smith, L. D., and B. C. Coull. 1987. Juvenile spot (Pisces) and grass shrimp predation on meiobenthos in muddy and sandy substrata. Journal of Experimental Marine Biology and Ecology 105: $123-136$.

Sousa, W. P. 1985. Disturbance and patch dynamics on rocky intertidal shores. Pages 101-124 in S. T. A. Pickett and P. S. White, eds. The ecology of natural disturbance and patch dynamics. Academic Press, Orlando, Fla.

Stancyk, S. E., H. M. Golde, P. A. Pape-Lindstrom, and W. E. Dobson. 1994. Born to lose. I. Measures of tissue loss and regeneration by the brittlestar Microphiopholis gracillima (Echinodermata: Ophiuroidea). Marine Biology 118:451-462.

Strathmann, M. F. 1987. Reproduction and development of marine invertebrates of the northern Pacific coast. University of Washington Press, Seattle.

Veblen, T. T. 1985. Stand dynamics in Chilean Nothofagus forests. Pages 35-51 in S. T. A. Pickett 
and P. S. White, eds. The ecology of natural disturbance and patch dynamics. Academic Press, Orlando, Fla.

Vitousek, P. M. 1985. Community turnover and ecosystem nutrient dynamics. Pages 325-333 in S. T. A. Pickett and P. S. White, eds. The ecology of natural disturbance and patch dynamics. Academic Press, Orlando, Fla.

Vlas, J., de. 1979a. Annual food intake by plaice and flounder in a tidal flat area in the Dutch Wadden Sea, with special reference to consumption of regenerating parts of macrobenthic prey. Netherlands Journal of Sea Research 13:117-153.

$1979 b$. Secondary production by tail regeneration in a tidal flat population of lugworms (Arenicola marina) cropped by flatfish. Netherlands Journal of Sea Research 13:362-393.

1985. Secondary production by siphon regeneration in a tidal flat population of Macoma balthica. Netherlands Journal of Sea Research 19:147-164.

Vrijenhoek, R. C. 1985. Animal population genetics and disturbance: the effects of local extinctions and recolonizations on heterozygosity and fitness. Pages 265-303 in S. T. A. Pickett and P. S. White, eds. The ecology of natural disturbance and patch dynamics. Academic Press, Orlando, Fla.

Wilson, W. H., Jr. 1981. Sediment-mediated interactions in a densely populated infaunal assemblage: the effects of the polychaete Abarenicola pacifica. Journal of Marine Research 39:735-748. 1990. Competition and predation in marine soft-sediment communities. Annual Review of Ecology and Systematics 21:221-241.

Woodin, S. A. 1982. Browsing: important in marine sedimentary environments? spionid polychaete examples. Journal of Experimental Marine Biology and Ecology 60:35-45.

1984. Effects of browsing predators: activity changes in infauna following tissue loss. Biological Bulletin (Woods Hole) 116:558-573.

1985. Effects of defecation by arenicolid polychaete adults on spionid polychaete juveniles in field experiments: selective settlement or differential mortality. Journal of Experimental Marine Biology and Ecology 87:119-132.

Woodin, S. A., and R. Marinelli. 1991. Biogenic habitat modification in marine sediments: the importance of species composition and activity. Symposium of the Zoological Society of London 63:231-250.

Woodin, S. A., S. M. Lindsay, and D. S. Wethey. 1995. Process-specific recruitment cues in marine sedimentary systems. Biological Bulletin (Woods Hole) 189:49-58.

Zajac, R. N. 1985. The effects of sublethal predation on reproduction in the spionid polychaete Polydora ligni Webster. Journal of Experimental Marine Biology and Ecology 88:1-19. 